\title{
Disulphide Bond Containing Oligodeoxynucleotide Stabilizes DNA:RNA Duplex Structure
}

\author{
AJAY KUMAR \\ Galgotias University, Plot No. 2, Sector17A, Yamuna Expressway, Distt. Gautam Budh \\ Nagar, UP, India \\ ak.gupta59@rediffmail.com
}

Received 6 May 2012 / Accepted 20 May 2012

\begin{abstract}
Thermal stability of DNA: RNA duplex formation of disulphide bond containing oligodeoxynucleotide was studied using UV thermal melting $\left(\mathrm{T}_{\mathrm{m}}\right)$. The disulphide bond containing oligodeoxynucleotide increased the melting temperature of DNA:RNA duplex by $9.5^{\circ} \mathrm{C}$ to duplex containing unmodified oligodeoxynucleotide. The DNA: RNA duplex stability of disulphide bond containing oligodeoxynucleotide was also enhanced by $3{ }^{\circ} \mathrm{C}$ relative to duplex containing $\mathrm{C}-5$ propyne deoxyuridine substituted oligodeoxynucleotide.
\end{abstract}

Keywords: C-5 Thiopropyne thymidine substituted oligodeoxynucleotides, $\mathrm{T}_{\mathrm{m}}, \mathrm{C}-5$ propynedeoxyuridine oligodeoxynucleotide, Disulphide bond containing oligonucleotide.

\section{Introduction}

Synthetic oligodeoxynucleotides have greater potential to become a new type of rationally designed therapeutic agent ${ }^{1-3}$. These compounds interfere with the expression of selected genes through interactions with m RNA, genome $\mathrm{DNA}^{4,5}$ or regulatory proteins ${ }^{6-10}$. Antisense oligo deoxynucleotides recognize target mRNA sequence through Watson- Crick hydrogen bonding between $\mathrm{A}$ and $\mathrm{T}$ and $\mathrm{G}$ and $\mathrm{C}$. This recognition is highly specific and may lead to development of less toxic and more site specific therapeutic agents ${ }^{11}$. The use of oligodeoxynucleotides as antisense inhibitor of gene expression ${ }^{4,12}$ and probes for RNA processes $^{13-15}$ requires high affinity for RNA. It has been shown in the past that chemical modification of oligodeoxynucleotides can improve their therapeutic potential ${ }^{16,17}$. The modifications may be carried out at base, sugar or backbone of oligodeoxynucleotides. The C-5 propyne analogs of 2'- deoxycytidine significantly enhanced the affinity to double helix formation with single strand RNA, relative to thymidine and 5- methyl-2deoxycytidine ${ }^{18}$. To improve the affinity of single strand ligand towards single strand RNA various other successful modifications have been carried out in the past ${ }^{19-27}$. Recent candidates of such chemically modified oligonucleotide analogs include $\mathrm{HNA}^{28}$, locked nucleic acid (LNA) ${ }^{29,30}, 2^{\prime}$-MOE-RNA and related $2^{\prime}$-O-modified $\mathrm{RNA}^{31}$, PNA and modifications thereof ${ }^{32}$, Morpholino-NAs ${ }^{33}$ and tricyclo-DNA ${ }^{34-36}$. Earlier we have shown that disulphide bond containing oligodeo xynu- cleotide stabilizes triplex structure ${ }^{41,42}$ as well as DNA: DNA double helix structure ${ }^{43}$. Here in, we describe binding of disulphide bond containing oligodeoxynucleotide with ribonucleic acid sequence. 


\section{Experimental}

\section{Synthesis of oligonucleotides}

The unmodified oligonucleotides (deoxy- as well as ribo-) and C-5 thiopropyne substituted thymidine containing oligonucleotide were synthesized, deprotected, purified as described else where ${ }^{37}$. Base composition analysis of oligonucleotides was carried out as described else where $^{37}$. Propyne oligonucleotide was synthesized using C-5-(1-propyne) -2'- deoxyuridine phosphoramidite (Glen Research). Preparation and purification of disulphide bond containing oligonucleotide was carried out as described earlier ${ }^{37,38}$.

\section{Synthesis of free thiol containing oligonucleotide (2a)}

The duplex containing free thiol groups was obtained by reducing the disulphide bond containing duplex. A portion of duplex $(\mathrm{R}+2)$ was separately treated with $100 \mathrm{mM}$ DTT overnight and dialyzed against water (4X2L) and dried. Duplex was dissolved in $500 \mathrm{uL}$ of PIPES buffer (100 mM, NaCl, $100 \mathrm{mM} \mathrm{MgCl} 2,100 \mathrm{mM} \mathrm{NaPIPES}$ ) and solution was stored at $4{ }^{\circ} \mathrm{C}$ overnight.

\section{Thermal denaturation studies}

The duplexes were prepared by mixing one is to one ratio of a DNA oligomers and complementary RNA target oligomer $(1.5 \mathrm{u} \mathrm{M}$ each) in PIPES buffer at $7 \mathrm{pH}$. The mixtures were heated to $90{ }^{\circ} \mathrm{C}$ and allowed to cool down slowly to room temperature. The melting studies were carried out on a Varian Carry UV- VIS Spectrophotometer equipped with thermoprogammer. Teflon -Stoppered $1 \mathrm{~cm}$ path length quartz cells were used. The melting was carried out under nitrogen atmosphere. Absorbance $(260 \mathrm{~nm})$ was monitored while temperature was raised from $8{ }^{\circ} \mathrm{C}$ at a rate of $0.5{ }^{\circ} \mathrm{C} / \mathrm{min}$.

\section{Results and Discussion}

The oligonucleotides synthesized are listed in Table $1 . \mathrm{T}_{\mathrm{m}}$ of the duplexes determined is listed in Table 2. $\mathrm{T}_{\mathrm{m}}$ profiles of the duplexes are shown in Figure 1. Ball and stick model of disulphide bond formed between two adjacent free thiol groups of C-5 Thiopropyne thymidines is shown in Figure 2. The duplexes were derived from oligonucleotides 1 to 3 and complementary single stranded RNA. The melting temperature (Table 2$)$ of the duplex $(\mathrm{R}+2)$ is higher by $9.5{ }^{\circ} \mathrm{C}$ and $3.0{ }^{\circ} \mathrm{C}$ relative to $(\mathrm{R}+1)$ duplex and $(\mathrm{R}+3)$ duplex respectively. It is interesting to note that duplex containing disulphide bonded oligonucleotide is relatively more stable to duplex containing propyne-substituted oligonucleotide. This stabilization may be due to the favorable geometry of disulphide bond present in the center of the oligonucleotide.

Table 1. Oligonucleotides synthesized

\begin{tabular}{|c|c|}
\hline S. No & Oligonucleotide Sequence \\
\hline $\mathrm{R}$ & 3' AAGAAAGAAAA 5' \\
\hline 1 & 5' \\
\hline \multirow[t]{3}{*}{2} & S-S \\
\hline & I I \\
\hline & 5’ TTCT T ТСТTТTC 3’ \\
\hline \multirow[t]{3}{*}{$2 a$} & HS SH \\
\hline & I I \\
\hline & 5’ТTCTT ТСТTТTC 3’ \\
\hline \multirow[t]{3}{*}{3} & rP Pr \\
\hline & I I \\
\hline & 5’ ТTCTТ ТСТTТТС 3' \\
\hline
\end{tabular}


Table 2. $\mathrm{T}_{\mathrm{m}}$ data of RNA/ DNA Duplexes

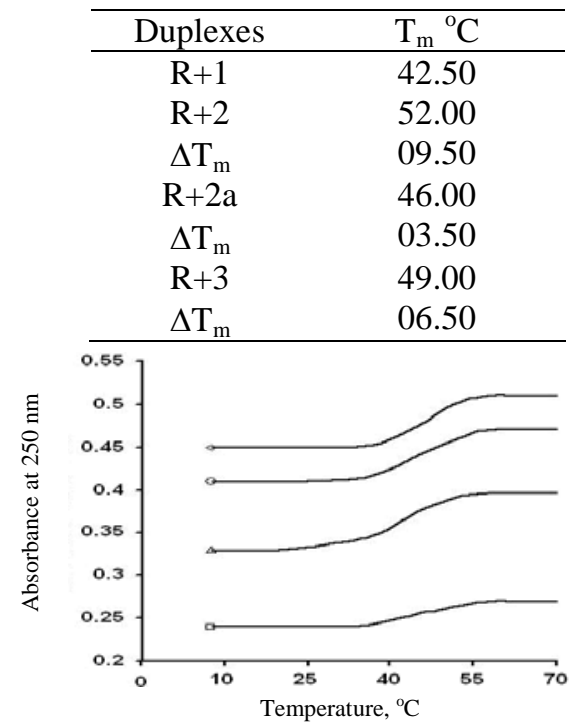

Figure 1. $T_{m}$ profile of RNA / DNA duplexes $(\Delta) R+1,(\circ) R+2,($ ) $R+2 a,(\diamond) R+3$

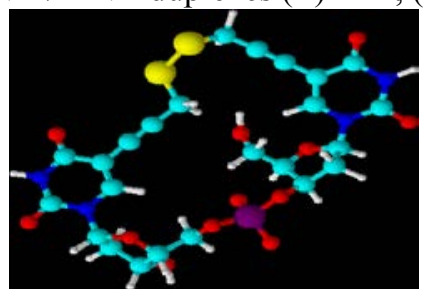

Figure 2. Disulhpide bond between two adjacent C-5 Thiopropyne thymidines

The oligodeoxynucleotide, 2a containing two free thiol groups increased the Tm of $(\mathrm{R}+2 \mathrm{a})$ duplex by $3.5{ }^{\circ} \mathrm{C}$ relative to $(\mathrm{R}+1)$ duplex. It has been shown that DNA hairpin containing disulphide cross link increased the $\mathrm{T}_{\mathrm{m}}$ by $21{ }^{\circ} \mathrm{C}$ relative to the wild type sequence $^{39,40}$. The oligodeoxynucleotides containing propyne analogs of 2-deoxyuridine and 2-deoxycytidine have been used to stabilize the duplexes ${ }^{18}$. The stabilization of duplex in case of cross linked oligonucleotide was due to the restriction in flexibility of duplex. The oligodeoxynucleotides containing C-5 propyne analogs of 2-deoxyuridine and 2-deoxycytidine stabilized duplexes due to $\pi-\pi^{*}$ interactions. The disulphide modified oligonucleotide contains triple bonds to promote $\pi-\pi^{*}$ interactions as well as a disulphide bond between the two adjacent deoxyuridines to restrict the conformation.

\section{Acknowledgement}

I acknowledge DST (India) for BOYSCAST Fellowship.

\section{References}

1. $\quad$ Bell N M and Micklefield J, Chem Bio Chem., 2010, 10, 2691-2703.

2. Tiemann K and Rossi J J, RNAi-based therapeutics - current status, Challenges and prospects, EMBO Mol Med., 2009, 1, 142-151.

3. Sibley C R, Seow Y and Wood M J A, Mol Ther., 2010, 18, 466-476.

4. Uhlmann E and Peyman A, Chem Rev., 1990, 90, 544-584. 
5. Helene C and Toulme J J, Biochem Biophys Acta, 1990, 1049, 99-105.

6. $\quad$ Tuerk C and Gold I, Science, 1990, 249(4968), 505-510.

7. Bock L C, Griffin L C, Lathans J A, VermassE H and Tool J J, Nature, 1992, 355(6360), 564- 566.

8. Wu H, Holecnberg J S, Tomich J, Chen J, Jones P A, Huang S H and Calame K L, Gene., 1990, 89, 203-209.

9. Harel -Bellan A, Brini A, Ferris D F, Robin P, Farrar W L, Nucleic Acids Res., 1989, 17(11), 4077- 4087.

10. Bielinska A, Shivdasani R A, Zhang L and Nabel G J, Science, 1990, 250, 997-1001.

11. Stepenson M L, Zamecinik P C, Proc Nalt Acad Sci (USA), 1978, 75(1), 285-288.

12. Goodchild J, Bioconjugate Chem., 1990, 1(3), 165-187.

13. Lamond A I, Sproat B S, Ryder U and Hamm J, Cell., 1989, 58, 383-390.

14. Blencowe B J, Spoart B S, Ryder U, Barabino S and Lamond A I, Cell., 1989, 59, 531-539.

15. Barabino S M L, Spoart B S, Ryder U, Blencowe B J and Lamond A I, EMBO J., 1989, 8, 4171-4178.

16. Bennett C F and Swayze E E, Annu Rev Pharmacol Toxicol., 2010, 50, 259-293.

17. Kool E T, Acc Chem Res., 2002, 35, 936-943.

18. Froehler B C, Wadwani S, Terhorst T J and Gerrard S R, Tetrahedron Lett., 1992, 33(37), 5307-5310.

19. Gryaznov S and Chen J, J Am Chem Soc., 1995, 116, 3143-3144.

20. Jones R J, Swaminathan S, Milligan J F, Wadwani S, Froehler B C and Metteucci D, J Am Chem Soc., 1993, 115(21), 9816-9817.

21. Beaucage S L and Iyer R P, Tetrahedron, 1993, 49, 6123-6194.

22. Verma R S, Syn Lett., 1993, 621-637.

23. Sanghvi Y S and Cook P D, Carbohydrate Modification in Antisense Research, ACS Symp Series, 1994, 580-581.

24. Egholm M, Buchardt O, Nielsen P E and Berg R H, J Am Chem Soc., 1992, 14, 1895-1897.

25. Nielsen P E, Egholm M, Berg R H and Buchardt O, Science, 1990, 254, 1497-1500.

26. Gryaznov S and Chen J K P, J Am Chem Soc., 1994, 116, 3143-3144.

27. Aerschot A V, Verheggen I, Hendrix C and Herdewijn P, Angew Chem Ind Ed Engel., 1995, 34, 1338-1339.

28. Kang H, Fisher M H, Xu D, Miyamoto Y J, Marchand A, Van Aerschot A, Herdewijn P and Juliano R L, Nucleic Acids Res., 2004, 32, 4411-4419.

29. Veedu R N and Wengel J, Chem Biodivers., 2010, 7, 536- 542.

30. Imanishi T and Obika S, Chem Commun., 2002, 1653-1659.

31. Prakash T P, Kawasaki A M, Wancewicz E V, Shen L, Monia B P, Ross B S, Bhat B and Manoharan M, J Med Chem., 2008, 51, 2766- 2776.

32. Nielsen P E, Chem Biodivers., 2010, 7, 786-804.

33. Moulton J D and Jiang S, Molecules, 2009, 14, 1304-1323.

34. Ittig D, Liu S, Renneberg D, Schümperli D and Leumann C J, Nucleic Acids Res., 2004, 32, 346-353.

35. Renneberg D, Schümperli D and Leumann C J, Nucleic Acids Res., 2002, 30, 2751-2757.

36. Ittig D, Gerber A B and Leumann C J, Nucleic Acids Res., 2011, 39, 373-380.

37. Chaudhuri N C and Kool E T, J Am Chem Soc., 1995, 11, 10434-10442.

38. Kumar A, IUP J Chem., 2009, Vol. II(4), 47-54.

39. Glick G D, Osborne S E, Knitt D S and Marino Jr J P, J Am Chem Soc., 1992, 114, 5447-5448.

40. Glick G D, J Org Chem., 1991, 56, 6746-6747.

41. Kumar A, E- J Chem., 2011, 8(2), 507-512.

42. Kumar A, Inter J Appl Bio Pharm Technol., 2010, 1(2), 404-409.

43. Kumar A, IUP J Chem., 2011, 4(1), 91-97. 